\title{
Agrarian Reform in Latin America
}

An Annotated Bibliography

Land Economics Monograph Series No. 5

This massive bibliography contains more than five thousand annotated entries covering virtually all the materials-books, journal articles, pamphlets, unpublished reports, etc.-relating to land tenure and reform in Latin America. It will be the first work of its kind since 1964 and will serve researchers, scholars, and administrators throughout the world who are studying these vital topics. Separate bibliographies are included for each Latin American, Central American, and Caribbean country, along with general bibliographies on each area and one covering general bibliographic works. Author and subject indexes are also included,

Wisconsin

1976

299950301

299950344

$£ 12.00$

$£ 4.50$

\section{An Auto Worker's Journal}

\section{The UAW from Crusade to One-Party Union} Frank Marquart

This book traces the evolution of the United Auto Workers-and, by extension, U.S. industrial unionism as a whole-through the experiences of a man who began as a bench hand in 1914 and retired from the Iriternational UAW education department in 1963. The author's thesis is stated in his first chapter: "Time was when the American labour movement was respected as a force for social justice. Certainly this view was widely held in early CIO days. Today, however, even liberals regard unions as bureaucratized self-interest establishments. . . . But I know this is not the end of the process. ...."

Pennsylvania State

1976

271011963

$\mathfrak{f 6 . 0 0}$

\section{Born to be}

\section{Taylor Gordon}

Originally published in 1929, Born to $B e$ is an authentic, engaging document of the Harlem Renaissance of the 1920's. It is the story of the only Black family in the booming Montana town of White Sulphur Springs; of Emmanuel Taylor Gordon's rise from messenger for a thriving local brothel to chauffeur, cook, and private railway car attendant for the financier and circus impresario John Ringling; and of Gordon's international career as a singer of Afro-American spirituals. This reprint reproduces the original foreword by Carl Van Vechten, then the most famous White supporter of young Black artists, and the illustrations by Miguel Covarrubias, to which have been added a selection of photographs of Gordon and his associates.

$\begin{array}{llll}\text { Washington } & 1976 & 295953527 & £ 6.00 \\ & & 29595428 & 0\end{array}$

\section{Cultural Regions of the United States}

\section{Raymond D. Gastil}

Although there have been regional analyses of the United States using such bases as economics or physical geography, this is the first modern analysis of the country based upon cultural regions. These regions are defined, first, by the variations in the cultures of people that dominated the original settlement, and secondarily by variations that dominated later settlements, as well as by cultural traits developed subsequently. This study will be invaluable as a new yardstick for understanding national diversity; as a basis for more effective implementation of public policy; and as a vehicle citizens can use to develop local consciousness and pride.

Washington

1976

295954264

$£ 7.80$

\section{AMERICAN UNIVERSITY PUBLISHERS GROUP}

70 Great Russell Street, London WC1B 3BY. Tel: 01-405 0182 


\section{The Unwritten War}

American Writers and the Civil War

\section{Daniel Aaron}

In this book Professor Aaron distinguishes between those authors, such as Henry James and Mark Twain, who dealt with the War only marginally, and others, for example Melville and Faulkner, who were deeply affected by it. He explores the extent to which the War changed the direction of American literature and considers how far American writers perceived its moral and historical implications. $£ 2.95$

Galaxy Books

\section{Strain of Violence \\ Historical Studies of American Violence and \\ Vigilantism}

\section{Richard Maxwell Brown}

Violence is a persistent pattern in American behaviour and in these eight essays the author, drawing on the major incidents of violence in American history, examines the origins of the phenomenon and provides a historical chronicle of its development. $£ 7 \cdot 50$

\section{The Life and Times of Theodore Roosevelt}

\section{William Henry Harbaugh}

Denounced as a dangerous authoritarian, dismissed as a noisy buffoon, praised as a progressive and a reformer, Roosevelt has been claimed by both arch-conservatives and radicals, interventionists and isolationists. This critical reappraisal of one of America's most popular political heroes gives a complete constructive achievements to his private life, inner tensions, and personal tragedies. Paper covers $£ 2.95$

\section{A Biography of the Constitution of the United States}

\section{Broadus Mitchell and Louise Pearson Mitchell}

This second edition of a book first published in 1964 includes new material on the debate at the Constitutional Convention on impeachment, the impeachment and trial of Andrew Johnson, the three most recent amendments to the Constitution, the abortion controversy in the courts, and the one man one vote issue. Second edition $\mathfrak{f 6} .75$

\section{Oxford University Press}




\section{The Role of the Supreme Court in American Government Archibald Cox}

In this study Professor Cox discusses the legitimacy of the Supreme Court, its influential role in interpreting the Constitution, and its importance as an instrument of social reform. Many topics of current or recent public interest are investigated: not only the Watergate affair, of which Professor Cox as Special Prosecutor has personal as well as legal knowledge, but other issues crucial to civil liberty: racial discrimination, the freedom of the press, and abortion. $£ 2 \cdot 75$

\section{History and American Society Essays of David M. Potter Edited by Don E. Fehrenbacher}

This collection of sixteen of Professor Potter's most significant essays includes some that are considered classics of intellectual and social thought; five of the others were published for the first time when the collection first appeared in 1973. Together they make an important contribution to the understanding of the American past. The hard-cover edition remains available at $£ 4 \cdot 50$. Paper covers $£ 2 \cdot 25$

\section{The Story of the Declaration of Independence \\ Dumas Malone}

This handsome paperback version of the second edition of this book, first published in 1975, celebrates America's two-hundredth birthday. It describes not only the evolution of the Declaration of Independence, but contains biographies of every person who signed it. The illustrations include a new section of English political cartoons. The cloth edition remains available at $£ 8 \cdot 75$. Second edition illustrated paper covers $£ 4 \cdot 20$ Galaxy Books

The Spirit of "76

The Growth of American Patriotism before Independence

\section{Carl Bridenbaugh}

This interpretive essay by one of America's leading colonial historians explores the growth of a particular American nationalism in the years between the English settlement at Jamestown in 1607 and the Declaration of Independence in 1776. Professor Bridenbaugh sheds new light on the ways in which the sense of being American had

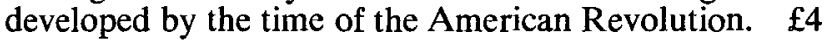

\section{Oxford University Press}




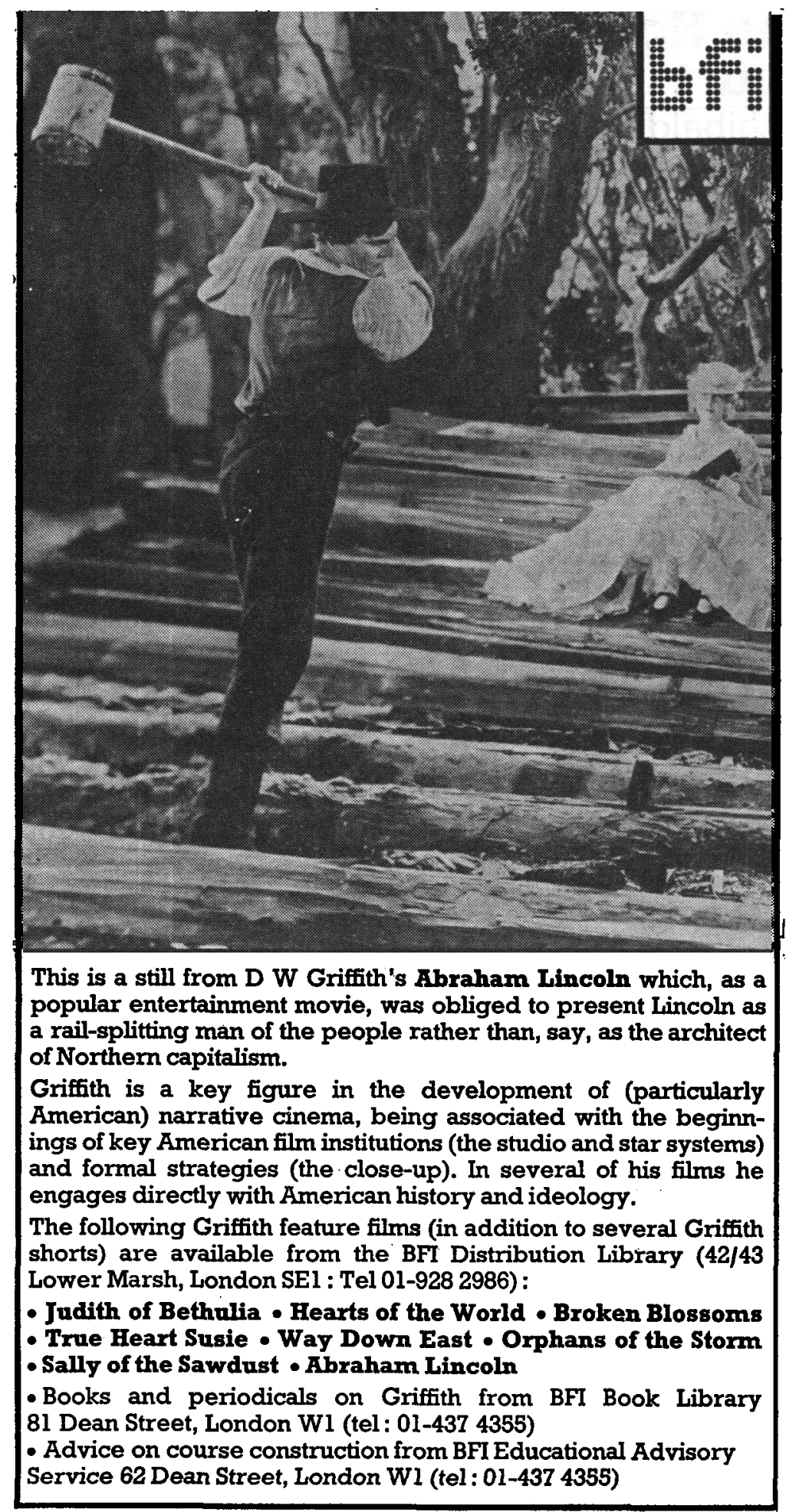




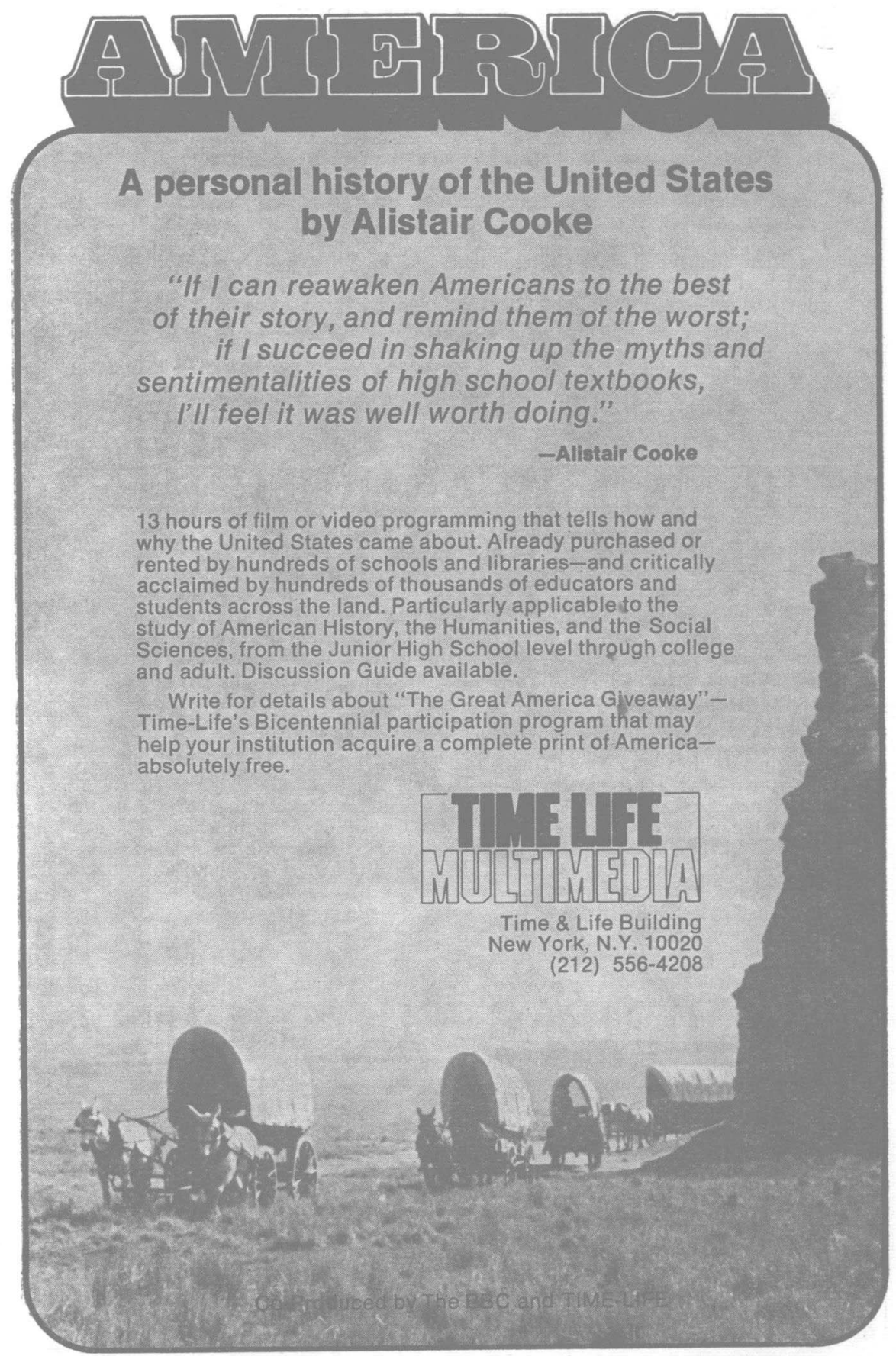




\section{THE RESERVATION}

by Ted C. Williams. The son of a Turtle Clan sachem chief and Medicine Man, Ted Williams grew up on the Tuscarora Indian Reservation near Niagara Falls, New York, in the 1930s and 1940s. In the stories that comprise The Reservation, Williams recounts many of the old traditions that have since disappeared and can never be recaptured. Vivid characterizations of unique tribal elders, partners in difficult marriages, happy-and unhappy -children appear alongside tales of communal efforts led by the women to sabotage Robert Moses' New York State Power Project, which threatened to destroy a large portion of the reservation. Williams writes of the land as life and identity for the whole tribe, of ceremonies-both ancient Iroquois and Christian-that highlight each year, and of the experience of leading the young men in their Midwinter Festival hunt. He tells what it is to be a Tuscarora.

ISBN $0-8156-0119-0 \quad 24$ illustrations $\$ 12.00$

\section{THE AMERICAN JOURNALS OF LT. JOHN ENYS}

edited by Elizabeth Cometti. John Enys, a young British ensign, arrived in Quebec in the spring of 1776. During the next ten years he served garrison duty and fought in the battle off Valcour Island and in raids against the frontiers of New York and Vermont. Rather than returning to England with his regiment in 1787 he traveled through the former colonies to Norfolk, Virginia. The tales of his travels, mostly by public conveyances in the dead of winter, make fascinating reading. He was amazed at his warm receptions in Boston, New York, and Philadelphia. One of the highlights of his trip was a day spent with George Washington and his family at Mt. Vernon. As a soldier, Enys never missed the opportunity to visit battle sites of the Revolution, and in a field-guide style he describes how the sites looked in 1787. This lavishly illustrated book draws from sources in the United States, Canada, and Great Britain. Published by the Adirondack Museum and Syracuse University Press.

ISBN 0-8156-0121-2 50 illustrations \& maps $\$ 17.95$

\section{"REMEMBER THE LADIES"}

New Perspectives on Women in American History

edited by Carol $V_{\text {. }} R$. George. A fresh approach to the study of women in history, from 17 th century religion to 20 th century politics, in significant essays collected in honor of Nelson M. Blake.

ISBN 0-8156-0110-7

$\$ 10.00$

From your local bookseller or prepaid from

SYRACUSE UNIVERSITY PRESS

Syracuse, New York 13210 


\section{San Antonio}

\section{A Historical and Pictorial Guide}

\section{By Charles H. Ramsdell Revised Edition by Carmen Perry}

For centuries, San Antonio has been at the heart of change in the Southwest: first as a Spanish mission for Native American inhabitants of the area, later as a Mexican stronghold, next as a part of the expanding frontier, and now as a dynamic modern city. This historic background, along with the multicultural contributions of its various residents, has made it one of America's most distinctive cities. This book captures all the colour, past and present, of this fascinating place. It recounts early Texas history in considerable detail, relying on manuscript and newspaper descriptions and photographs from the nineteenth century.

308 pages

292775253

$£ 3.00$ (paper only)

\section{American Folklife}

\section{Edited by Don Yoder}

Knowledge of phenomena universally present, such as folk custom and folk belief, can help to explain ways of thought and behaviour in twentieth-century America. American Folklife, a unique collection of essays dedicated to the presentation of American tradition, broadens our understanding of the regional differences and ethnic folkways that colour American life. The book relates folklife research to history, anthropology, cultural geography, architectural history, ethnographic film, folk technology, folk belief, and ethnic tensions in American society.

420 pages

292703082

£9.25

\section{UNIVERSITY OF TEXAS PRESS}

70 Great Russell Street, London WC1B 3BY. Tel: 01-405 0182

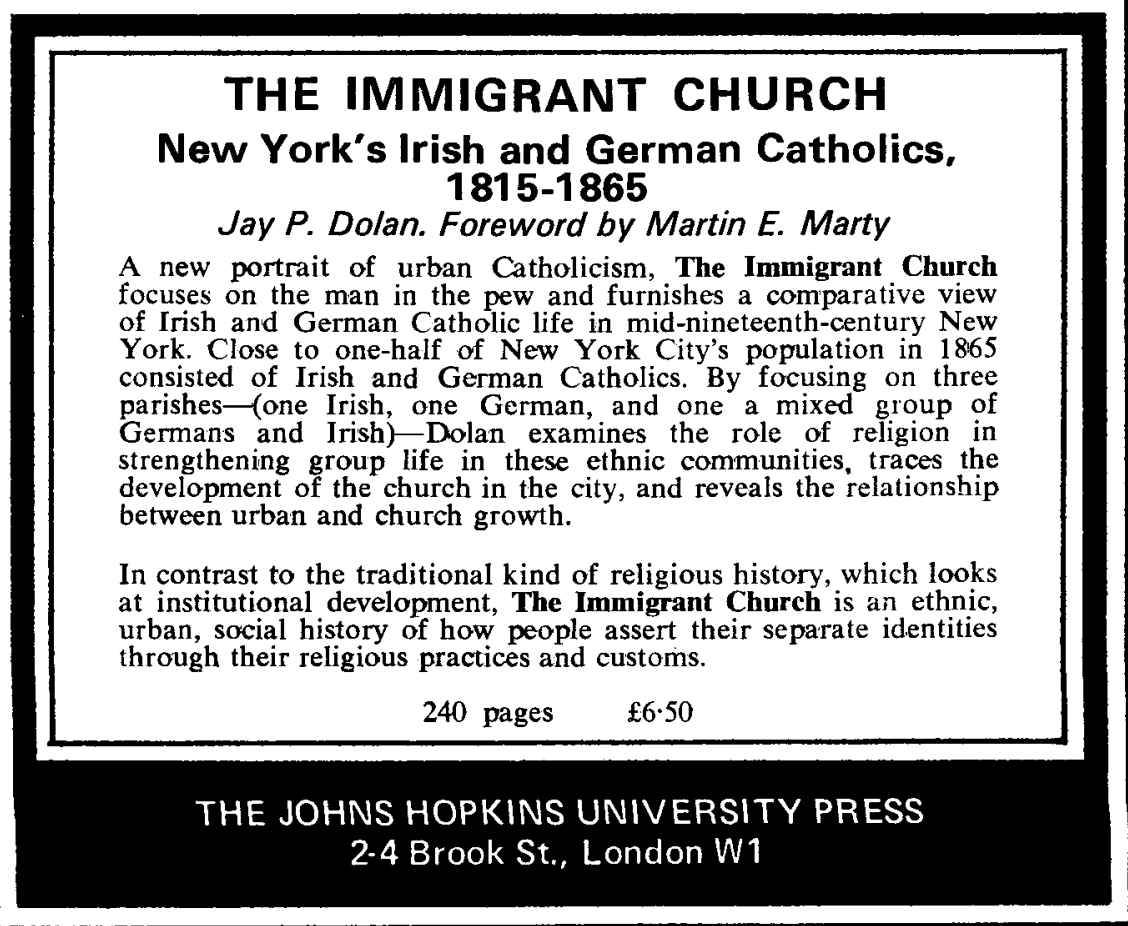




\section{Johns Hopkins}

\section{THE PUBLIC IMAGE OF BIG BUSINESS IN AMERICA, 1880-1940 \\ A Study in Social Change \\ Louis Galambos}

Providing a new look at a dynamic period of American history, this book describes and analyzes the changes in American middleclass attitudes toward the large corporation from 1880 to the beginning of World War II. Galambos describes how middle-class animosity toward the giant trusts followed a cyclical pattern which peaked during the depression of 1890 .

In subsequent decades, the author expiains, a gradual process of accommodation developed between the corporation and most middle-class occupational groups. By analyzing various trade and professional publications, Galambos shows that this "corporate culture," attuned to the needs of bureaucracy, was so firmiy rooted by the end of the 1920s that Americans were not particularly hostile toward big business, even during the depression of the 1930 s.

Using data provided by content analysis in addition to more traditional sources, the author offers a new means of evaluating the cultural consequences of the major organizational, economic, and political developments during this period.

$$
360 \text { pages } £ 9 \cdot 75
$$

\section{WESTERN RIVER TRANSPORTATION The Era of Early Internal Development, 1810-1860}

\section{Erik F. Haites, James Mak and Gary M. Walton}

Much attention has been given to the development of canals and railroads and its effect on American economic growth in the nineteenth century. However, Western River Transportation challenges current orthodoxy in a new examination of the role of the river system in the American West before the Civil War.

The authors provide a detailed portrait of the workings of the river transportation system, the chief carrier of freight at that time, through a systematic and quantitative analysis of government documents and primary sources. They skilfully depict the evolution of the role of the government in the promotion of transportation improvement, the effects of increases in productivity, the rates of profit for various crafts, and many other facts and trends of the river system which influenced the American West.

$$
240 \text { pages } £ 8 \cdot 15
$$




\section{Johns Hopkins}

\section{COLONIAL AND HISTORIC HOMES OF MARYLAND}

\section{Etchings by Don Swann}

Text by Don Swann, Jr. Foreword by F. Scott Fitzgerald

This unique treasury of etchings by famed Baltimore etcher Don Swann, surveys Maryland homes built between 1642 and 1830 . It reproduces one hundred etchings previously available only in a 200-copy limited edition.

Each etching is accompanied by a descriptive text by Don Swann, Jr., which records the histories of the houses, legends about previous owners, and specific architectural features. Sporting such names as Cuthbert's Fortune and Hard Bargain, the houses abound in fascinating stories collected by father and son during four summers of travel. Endpaper maps show the locations where many of the historic dwellings still stand.

Using a variety of techniques-drypoint, soft ground, and aquatone -Swann's etchings of these historic dwellings are a timely and lasting remembrance of our colonial past.

$$
224 \text { pages } £ 22 \cdot 75
$$

\section{REPRESENTATIVE GOVERNMENT AND THE REVOLUTION}

\section{The Maryland Constitutional Crisis of 1787}

\section{Edited by Melvin Yazawa}

This selection of documents from the paper money emission controversy in Maryland in 1787 deals with the question of separation of powers within the American system of government, a question that is as important for our age as it was for the generation of the Founding Fathers. Yazawa makes accessible, in the first modern edition, materials fundamental to a study of the intellectual history of the Confederation and provides an introduction that describes the historical context and key issues of the controversy.

The essays of Samuel Chase, Thomas Stone, William Paca, and Alexander Contee Hanson trace the debate over the role of popular sovereignty in the realm of ordinary politics. While Alexander Hamilton, James Madison, and John Jay described the mechanics and institutions of a federal republic, the Maryland polemicists contested the more abstract issues of representative government: the nature of government and society, the limits of law and sovereignty, and the quality of representation.

208 pages $\mathfrak{f 6} .50$ 


\section{BRITISH ASSOCIATION FOR AMERICAN STUDIES}

This Association was founded in 1955 to promote the study of the United States within the United Kingdom. It welcomes applications for membership from people interested in the history, society, government and politics, economics, geography, literature and thought of the United States. It publishes a Newsletter twice yearly, holds an Annual Conference, and provides other services for its members from time to time. Enquiries concerning current subscription rates and applications for membership should be addressed to the Secretary, Mr Alan Graham, Department of Modern History, The Queen's University of Belfast, Belfast, Northern Ireland, $\mathrm{BT}_{7}$ INN.

\section{NOTES FOR CONTRIBUTORS}

I. All contributions and editorial correspondence should be sent to: The Editor, Journal of American Studies, Department of American Studies, The University, Manchester Mr3 9PL, England.

2. Articles should generally contain about 5000 words. Longer or shorter articles, or articles in two or more parts, may be accepted by arrangement with the Editor.

3. Submission of an article is taken to imply that it has not previously been published, or is not being considered for publication elsewhere.

4. Contributions should be clearly typed in double spacing, preferably on $\mathbf{A}_{4}$ paper, with a wide left-hand margin. Diagrams and maps may be included by arrangement with the Editor.

5. Footnotes should be used sparingly: in general, to give sources of direct quotations, references to main authorities on disputable questions, and evidence relied on for a new or unusual conclusion. They should be numbered in one sequence throughout the article, and should preferably be typed in double spacing at the end of the article.

6. Contributors should keep one copy of the typescript for correcting proofs.

7. Notes intended for the Editor or printer should be on a separate sheet.

8. First proofs may be read and corrected by contributors provided that they can give the Editor an address through which they can be reached without delay and can guarantee to return the corrected proofs to the Editor, by airmail where necessary, within ten days of receiving them.

9. Correction should be kept to an absolute minimum. It should be confined to errors of the typist or printer unless the Editor authorizes otherwise.

10. Contributors of articles and review articles receive 25 free separates. Extra copies may be ordered according to the scale of charges.

11. Contributors need not be members of the British Association for American Studies. Unsolicited typescripts can only be returned to overseas contributors who send International Reply Coupons (not postage stamps).

12. Contributors of accepted articles will be asked to assign their copyrights, on certain conditions, to Cambridge University Press, to help protect their material, particularly in the U.S.A. 


\section{Volume Io Number I April 1976}

\section{JOURNAL OF \\ AMERICAN \\ STUDIES}

page I GWENDA Morgan

'The Privilege of Making Laws';

The Board of Trade, the Virginia Assembly

and Legislative Review, 1748-1754

17 M. J. HeAle

Harbingers of Progressivism:

Responses to the Urban Crisis in New York, c. $1845^{-1} 860$

37 Bob Lawson-Peebles

Henry George the Prophet

53 Eric Mottram

'The Persuasive Lips':

Men and Guns in America, the West

85 Kathry SutherLand

Walter Scott and Washington Irving:

'Editors of the land of Utopia'

9I Ursui.a Mackenzie

John Barth's Chimera and the Strictures

of Reality

103 Charles Swann

A note on The Blithedale Romance, or

'Call him Fauntleroy'

I05 A Guide to Manuscripts relating to America in Great Britain and Ireland

IO9 Book Reviews

129 Theses on American Topics in Progress and Completed at British Universities

(C) Cambridge University Press 1976.

CA M B I D GE UNIVERSITY PRESS

Bentley House, 200 Euston Road, London NWI $2 \mathrm{DB}$

32 East $57^{\text {th }}$ Street, New York, N.Y. 10022 